NASA/TM-2010-216242

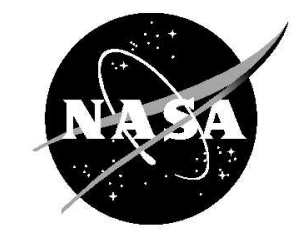

\title{
Measuring Crack Length in Coarse Grain Ceramics
}

Jonathan A. Salem and Louis J. Ghosn

Glenn Research Center, Cleveland, Ohio 


\section{NASA STI Program . . . in Profile}

Since its founding, NASA has been dedicated to the advancement of aeronautics and space science. The NASA Scientific and Technical Information (STI) program plays a key part in helping NASA maintain this important role.

The NASA STI Program operates under the auspices of the Agency Chief Information Officer. It collects, organizes, provides for archiving, and disseminates NASA's STI. The NASA STI program provides access to the NASA Aeronautics and Space Database and its public interface, the NASA Technical Reports Server, thus providing one of the largest collections of aeronautical and space science STI in the world. Results are published in both non-NASA channels and by NASA in the NASA STI Report Series, which includes the following report types:

- TECHNICAL PUBLICATION. Reports of completed research or a major significant phase of research that present the results of NASA programs and include extensive data or theoretical analysis. Includes compilations of significant scientific and technical data and information deemed to be of continuing reference value. NASA counterpart of peer-reviewed formal professional papers but has less stringent limitations on manuscript length and extent of graphic presentations.

- TECHNICAL MEMORANDUM. Scientific and technical findings that are preliminary or of specialized interest, e.g., quick release reports, working papers, and bibliographies that contain minimal annotation. Does not contain extensive analysis.

- CONTRACTOR REPORT. Scientific and technical findings by NASA-sponsored contractors and grantees.
- CONFERENCE PUBLICATION. Collected papers from scientific and technical conferences, symposia, seminars, or other meetings sponsored or cosponsored by NASA.

- SPECIAL PUBLICATION. Scientific, technical, or historical information from NASA programs, projects, and missions, often concerned with subjects having substantial public interest.

- TECHNICAL TRANSLATION. Englishlanguage translations of foreign scientific and technical material pertinent to NASA's mission.

Specialized services also include creating custom thesauri, building customized databases, organizing and publishing research results.

For more information about the NASA STI program, see the following:

- Access the NASA STI program home page at http://www.sti.nasa.gov

- E-mail your question via the Internet to help@ sti.nasa.gov

- Fax your question to the NASA STI Help Desk at $443-757-5803$

- Telephone the NASA STI Help Desk at 443-757-5802

- Write to: NASA Center for AeroSpace Information (CASI) 7115 Standard Drive Hanover, MD 21076-1320 
NASA/TM-2010-216242

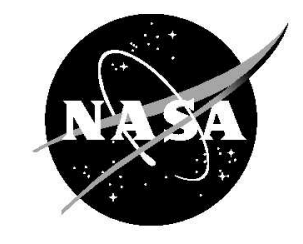

\section{Measuring Crack Length in Coarse Grain Ceramics}

Jonathan A. Salem and Louis J. Ghosn

Glenn Research Center, Cleveland, Ohio

National Aeronautics and

Space Administration

Glenn Research Center

Cleveland, Ohio 44135 
Level of Review: This material has been technically reviewed by technical management.

Available from

NASA Center for Aerospace Information

7115 Standard Drive

Hanover, MD 21076-1320
National Technical Information Service 5301 Shawnee Road Alexandria, VA 22312

Available electronically at http://gltrs.grc.nasa.gov 


\title{
Measuring Crack Length in Coarse Grain Ceramics
}

\author{
Jonathan A. Salem and Louis J. Ghosn \\ National Aeronautics and Space Administration \\ Glenn Research Center \\ Cleveland, Ohio 44135
}

\begin{abstract}
Due to a coarse grain structure, crack lengths in precracked spinel specimens could not be measured optically, so the crack lengths and fracture toughness were estimated by strain gage measurements. An expression was developed via finite element analysis to correlate the measured strain with crack length in four-point flexure. The fracture toughness estimated by the strain gaged samples and another standardized method were in agreement.
\end{abstract}

\section{Introduction}

Three techniques for measuring the fracture toughness of ceramics were standardized by the American Society for Testing and Materials (ASTM) (Refs. 1 to 3): the chevron-notched beam (VB), the single edged precracked beam (SEPB), and the surface crack in flexure. One issue concerning the techniques is the measurement of crack length, which has been identified as a major source of error in fatigue and fracture testing of metallic materials (Ref. 4). In ceramics, crack length measurement can be particularly difficult for a number of reasons: the small specimens typically used; the semi-opaque nature of many glass-based ceramics; the lack of plastic deformation at the crack tip which results in poor definition of the crack front; and high elastic modulus and low fracture toughness that result in small crack opening displacements. Ceramics with coarse grain structure, such as $\mathrm{ZnSe}$, alumina and $\mathrm{MgAlO}_{4}$ (spinel), present an additional difficulty because the crack front is difficult to delineate from the grain boundaries.

A simple and sensitive technique that can be used to estimate crack length and extension in SEPB specimens is the back-face strain gage (BFSG), as illustrated in Figure 1. BFS was previously used with metallic compact-tension specimens (Ref. 5), and in fine gain, opaque ceramics (Ref. 6). An additional benefit of strain gaging specimens is the ability to easily monitor the stability of the test, which is a requirement for the chevron-notch method.

This communication illustrates how BFS was employed to measure crack length and fracture toughness in a transparent, coarse grain spinel.

\section{Finite Element Analysis}

A two dimensional, plane strain finite element analysis (FEA) was performed to determine the BFS as a function of normalized crack length $(a / W)$ for the four-point flexure specimen. The FEA results from several specimen heights were combined by writing the BFS as:

$$
\varepsilon_{B F}=\varepsilon_{N} \frac{P\left(S_{o}-S_{i}\right)}{E B W^{2}}
$$

where $P$ is the applied force, $S_{i}$ and $S_{o}$ are the inner and outer spans, $E$ is the elastic modulus, $B$ is the thickness, $W$ is the height, $a$ is the crack length, and $\varepsilon_{N}$ is the normalized strain taken as a function of normalized crack length. The normalized crack length as a function of absolute normalized BFS as determined from the FEA is shown in Figure 2. For $a / W=0, \varepsilon_{N}=3 / 2$, which corresponds to that of an uncrack beam. The BFS is more sensitive to crack length changes for normalized lengths greater than $a / W$ $=0.3$. 


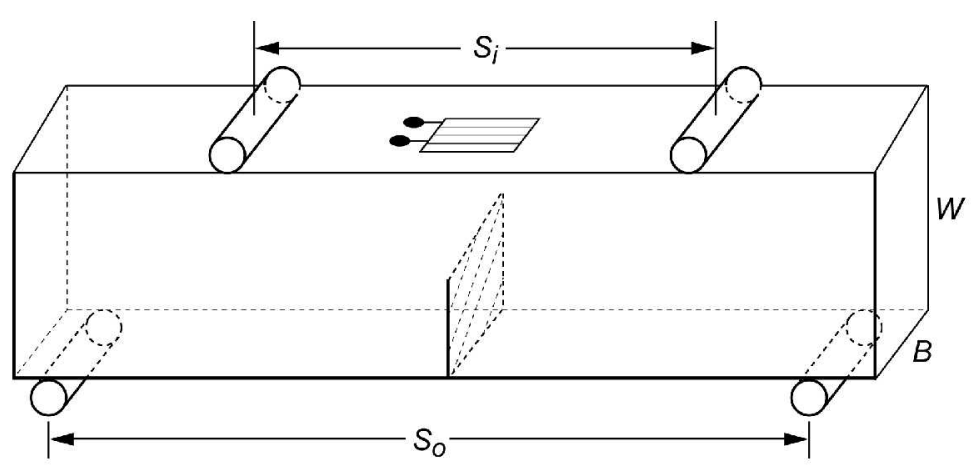

Figure 1.-Strain gage mounted on the back-face of a four-point flexure specimen.

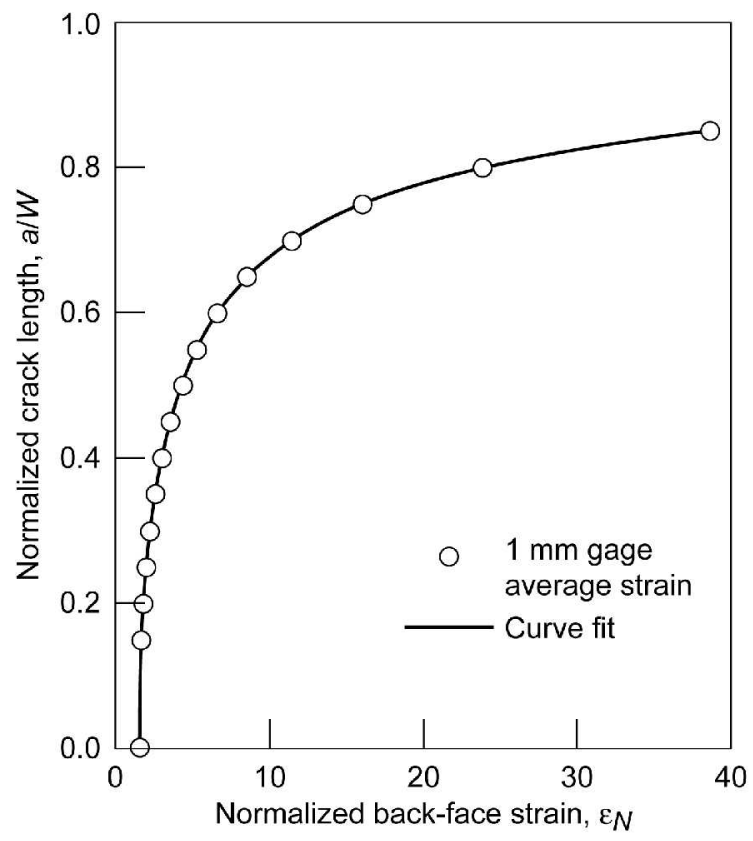

Figure 2.-Normalized crack length as a function of the absolute value of normalized back-face strain.

The FEA BFS results were fit via least squares regression:

$$
a / W=\frac{-0.0732199+0.7643304 \operatorname{Ln}\left|\varepsilon_{N}\right|-1.4386992\left(\operatorname{Ln}\left|\varepsilon_{N}\right|\right)^{2}}{1-2.1294083 \operatorname{Ln}\left|\varepsilon_{N}\right|-0.8732785\left(\operatorname{Ln}\left|\varepsilon_{N}\right|\right)^{2}-0.0197908\left(\operatorname{Ln}\left|\varepsilon_{N}\right|\right)^{3}}
$$

with the strain taken in absolute terms. Equation (2) resulted in correlation better than $r^{2}=0.999$.

Equation (2) requires knowledge of $\varepsilon_{N}$ to determine $a / W$. This can be estimated from the compliance observed $(\varepsilon / P)$ prior to stable crack extension, as shown in Figure 3. Then the mode $I$ stress intensity factor at any point during the test can be estimated from Equation (3), where $F(a / W)$ is the appropriate stress intensity factor coefficient (Ref. 3):

$$
K_{I}=\frac{P\left(S_{o}-S_{i}\right)}{B W^{3 / 2}} F(a / W)
$$

For fracture toughness measurements $\left(K_{I p b}\right)$, the maximum load observed and the initial crack length are employed in Equation (3). 

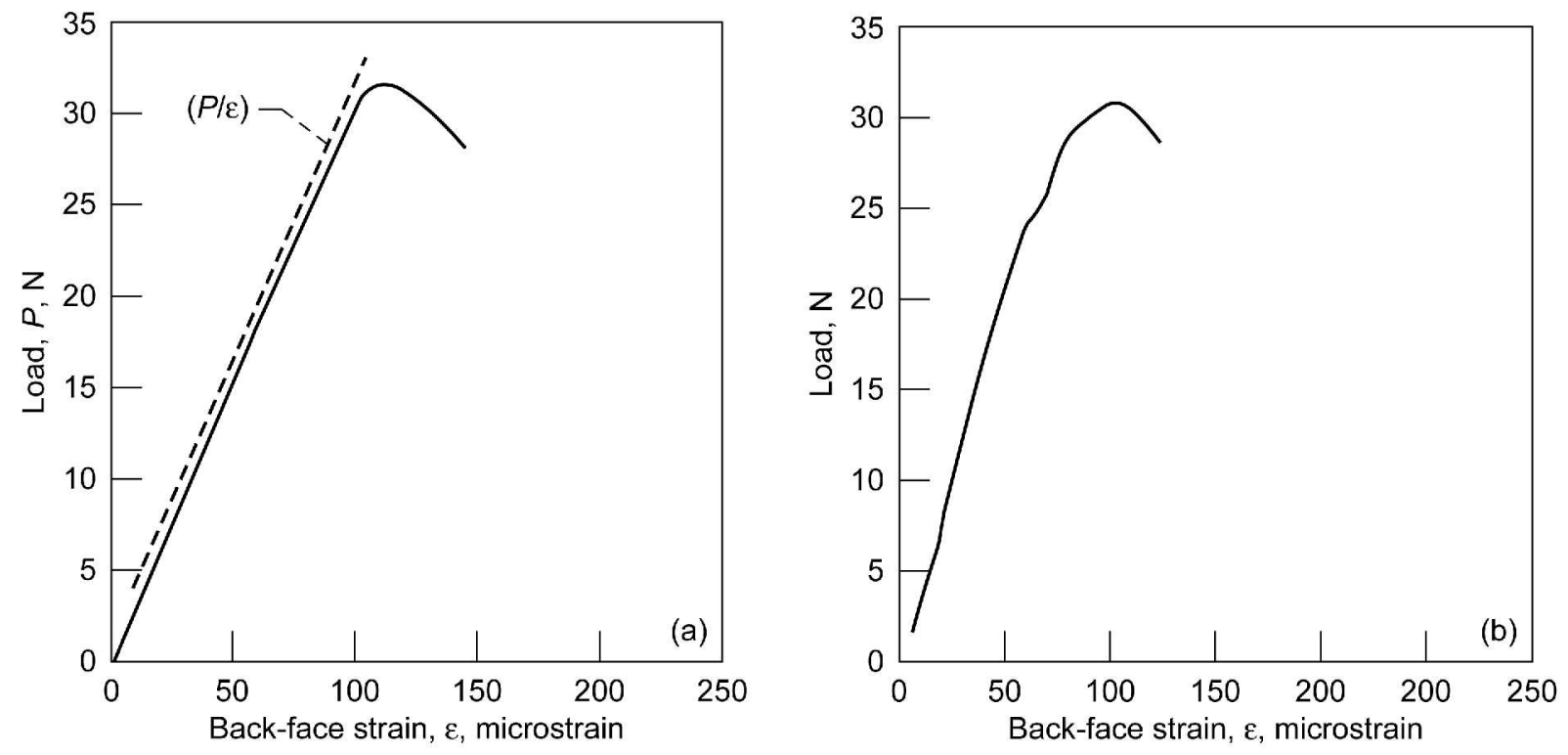

Figure 3.-Load as a function of BFS for spinel. (a) SEPB specimen. (b) VB specimen.
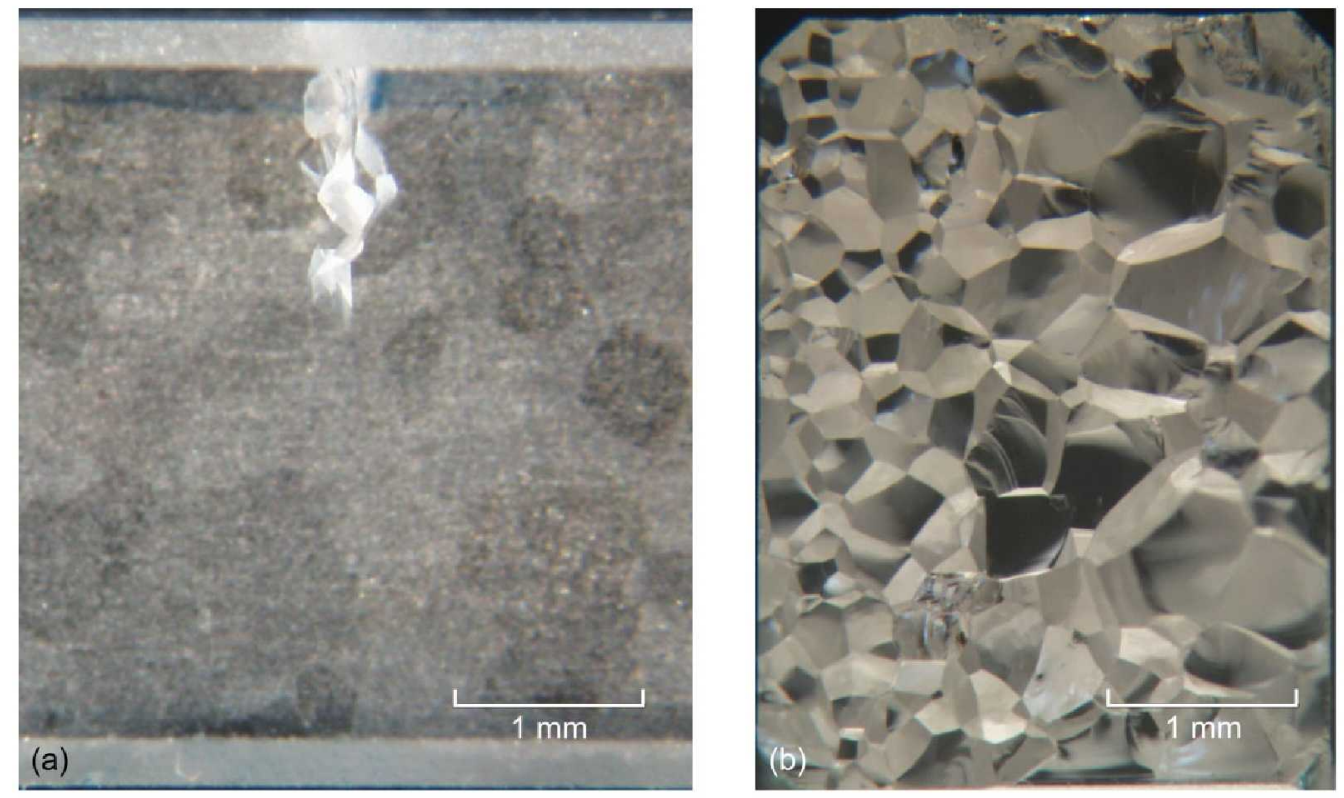

Figure 4.-(a) Precracked spinel specimen. (b) Post-fracture surface.

\section{Experimental Application}

During recent testing of a transparent spinel $\left(\mathrm{MgAlO}_{4}\right)$, crack length could not be measured to the operational requirements of ASTM C1421. The coarse structure and poor crack front definition, even with indicial illumination, can be seen in Figure 4. Thus BFS was employed to estimate the effective crack length and thereby estimate the fracture toughness $K_{l p b}$.

Precracking of 3.0 by $4.0 \mathrm{~mm}^{2}$ cross-sections was performed using a $4 \mathrm{~mm}$ bridge span with three, $5 \mathrm{~kg}$ Vickers indentations. A $1 \mathrm{~mm}$ strain gage was employed, and the precracked beams loaded between 20 and $40 \mathrm{~mm}$ spans at a rate of $0.2 \mathrm{~mm} / \mathrm{min}$ in air or dry nitrogen. Chevron-notched tests were also conducted using the same spans and a $1 \mathrm{~mm}$ strain gage. Example $P$-BFS curves are shown in Figure 3 
for SEPB and VB tests, and the results are summarized in Table 1. Good agreement occurs between the techniques. The elastic constants in Table 1 were determined in accordance with ASTM C1259 (Ref. 7).

\begin{tabular}{|c|c|c|c|c|}
\hline \multicolumn{3}{|c|}{$\begin{array}{c}\text { Fracture toughness } \\
(\mathrm{MPa} \sqrt{\mathrm{m})}\end{array}$} & \multirow[t]{2}{*}{$\begin{array}{l}\text { Poisson's } \\
\text { ratio, } v\end{array}$} & \multirow{2}{*}{$\begin{array}{c}\text { Elastic } \\
\text { modulus, } E \\
(\mathrm{GPa})\end{array}$} \\
\hline Configuration & $\begin{array}{c}\text { Air } \\
\left(75^{\circ} \mathrm{F}, \sim 60 \% \mathrm{RH}\right)\end{array}$ & Dry $\mathrm{N}_{2}$ & & \\
\hline SEPB & $1.32 \pm 0.05$ & $1.52 \pm 0.07$ & \multirow{2}{*}{0.26} & \multirow{2}{*}{$265 \pm 4$} \\
\hline VB & $1.48 \pm 0.14$ & $1.58 \pm 0.08$ & & \\
\hline
\end{tabular}

\section{Conclusion}

Back-face strain is a simple, inexpensive method for monitoring crack length in ceramic flexure specimens when the usual optical techniques are inadequate. The fracture toughness of a transparent spinel, as measured with BFS applied to the SEPB specimen, was comparable to that measured using the chevron-notch in flexure. Monitoring BFS in chevron-notched specimens is also very useful, as the stability is clearly determined.

\section{References}

1. J. A. Salem, L. J. Ghosn, M. G. Jenkins and G. D. Quinn, "Stress Intensity Factor Coefficients or Chevron-Notched Flexure Specimens and a Comparison Fracture Toughness Methods," Ceramic Engineering and Science Proceedings, 20 [3] 503-512 (1999).

2. J. A. Salem, G. D. Quinn, M. G. Jenkins, "Measuring the Real Fracture Toughness of Ceramics: ASTM C1421," pp. 531-553 in Fracture Mechanics of Ceramics: Active Materials, Nanoscale Materials, Composites, Glass, and Fundamentals, Edited by R.C. Bradt, D. Munz, M. Sakai and K. White, Springer, 2005.

3. ASTM C1421-07 "Standard Test Methods for Fracture Toughness of Advanced Ceramics," American Society for Testing and Materials Annual Book of Standards, Vol. 15.01, 2007.

4. W. G. Clark, and S. J. Hudak, "Variability in Fatigue Crack Growth Rate Testing," J. Test. and Eval., 3 [6] 454-476, (1975).

5. W. F. Deans and C. E. Richards, "A Simple and Sensitive Method of Monitoring Crack Extension and Load in Compact Fracture Mechanics Specimens Using Strain Gages," J. Test. and Eval., 7 [3] 147-154 (1979).

6. J. A. Salem, L. J. Ghosn and M. G. Jenkins "Back-Face Strain as a Method for Monitoring Stable Crack Extension," Ceramic Engineering and Science Proceeding, 9 [3] 587-594 (1998).

7. ASTM C1259-08 "Dynamic Young's Modulus, Shear Modulus, and Poisson's Ratio for Advanced Ceramics by Impulse Excitation of Vibration," American Society for Testing and Materials Annual Book of Standards, Vol. 15.01, 2008. 


\begin{tabular}{|c|c|c|}
\hline \multicolumn{2}{|c|}{ REPORT DOCUMENTATION PAGE } & $\begin{array}{l}\text { Form Approved } \\
\text { OMB No. 0704-0188 }\end{array}$ \\
\hline \multicolumn{3}{|c|}{ 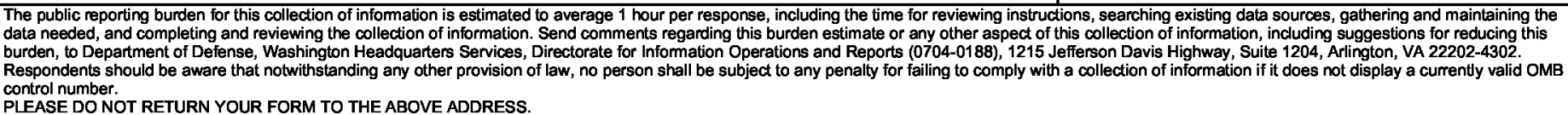 } \\
\hline $\begin{array}{l}\text { 1. REPORT DATE (DD-MM-YYYY) } \\
01-03-2010\end{array}$ & $\begin{array}{l}\text { 2. REPORT TYPE } \\
\text { Technical Memorandum }\end{array}$ & 3. DATES COVERED (From - To) \\
\hline \multirow{3}{*}{\multicolumn{2}{|c|}{$\begin{array}{l}\text { 4. TITLE AND SUBTITLE } \\
\text { Measuring Crack Length in Coarse Grain Ceramics }\end{array}$}} & 5a. CONTRACT NUMBER \\
\hline & & 5b. GRANT NUMBER \\
\hline & & 5c. PROGRAM ELEMENT NUMBER \\
\hline \multirow{3}{*}{\multicolumn{2}{|c|}{$\begin{array}{l}\text { 6. AUTHOR(S) } \\
\text { Salem, Jonathan, A.; Ghosn, Louis, J. }\end{array}$}} & 5d. PROJECT NUMBER \\
\hline & & 5e. TASK NUMBER \\
\hline & & $\begin{array}{l}\text { 5f. WORK UNIT NUMBER } \\
\text { WBS } 441261.04 .22 .04 .03\end{array}$ \\
\hline \multicolumn{2}{|c|}{$\begin{array}{l}\text { 7. PERFORMING ORGANIZATION NAME(S) AND ADDRESS(ES) } \\
\text { National Aeronautics and Space Administration } \\
\text { John H. Glenn Research Center at Lewis Field } \\
\text { Cleveland, Ohio 44135-3191 }\end{array}$} & $\begin{array}{l}\text { 8. PERFORMING ORGANIZATION } \\
\text { REPORT NUMBER } \\
\text { E-17229 }\end{array}$ \\
\hline \multirow{2}{*}{\multicolumn{2}{|c|}{$\begin{array}{l}\text { 9. SPONSORING/MONITORING AGENCY NAME(S) AND ADDRESS(ES) } \\
\text { National Aeronautics and Space Administration } \\
\text { Washington, DC 20546-0001 }\end{array}$}} & $\begin{array}{l}\text { 10. SPONSORING/MONITOR'S } \\
\text { ACRONYM(S) } \\
\text { NASA }\end{array}$ \\
\hline & & $\begin{array}{l}\text { 11. SPONSORING/MONITORING } \\
\text { REPORT NUMBER } \\
\text { NASA/TM-2010-216242 }\end{array}$ \\
\hline \multicolumn{3}{|c|}{$\begin{array}{l}\text { 12. DISTRIBUTION/AVAILABILITY STATEMENT } \\
\text { Unclassified-Unlimited } \\
\text { Subject Category: } 27 \\
\text { Available electronically at http://gltrs.grc.nasa.gov } \\
\text { This publication is available from the NASA Center for AeroSpace Information, 443-757-5802 }\end{array}$} \\
\hline
\end{tabular}

\section{SUPPLEMENTARY NOTES}

\section{ABSTRACT}

Due to a coarse grain structure, crack lengths in precracked spinel specimens could not be measured optically, so the crack lengths and fracture toughness were estimated by strain gage measurements. An expression was developed via finite element analysis to correlate the measured strain with crack length in four-point flexure. The fracture toughness estimated by the strain gaged samples and another standardized method were in agreement.

\section{SUBJECT TERMS}

Ceramics; Fracture toughness; Crack growth; Strain gages; Grain size

\begin{tabular}{|c|c|c|c|c|c|}
\hline \multicolumn{3}{|c|}{ 16. SECURITY CLASSIFICATION OF: } & \multirow{2}{*}{$\begin{array}{l}\text { 17. LIMITATION OF } \\
\text { ABSTRACT } \\
\text { UU }\end{array}$} & \multirow{2}{*}{$\begin{array}{l}\text { 18. NUMBER } \\
\text { OF } \\
\text { PAGES } \\
10\end{array}$} & \multirow{2}{*}{$\begin{array}{l}\text { 19a. NAME OF RESPONSIBLE PERSON } \\
\text { STI Help Desk (email:help@sti.nasa.gov) } \\
\text { 19b. TELEPHONE NUMBER (include area code) } \\
\text { 443-757-5802 }\end{array}$} \\
\hline $\begin{array}{l}\text { a. REPORT } \\
\mathrm{U}\end{array}$ & $\begin{array}{l}\text { b. ABSTRACT } \\
\mathrm{U}\end{array}$ & $\begin{array}{l}\text { c. THIS } \\
\text { PAGE } \\
\text { U }\end{array}$ & & & \\
\hline
\end{tabular}



